\title{
FARMING RED DEER ON A MIXED CROPPING UNIT
}

\section{J.A. STEVEN}

Farmer, Fairview, Timaru

\section{INTRODUCTION}

In early 1970 the few pioneer deer farmers were being watched while they learnt the techniques of domesticating the wild deer. Deer farmers are still being watched though most are not now pioneers. The systems have been studied, learnt and basically understood. The last 10 years have seen rapid growth in numbers of farmers involved and animals kept. Local Mid and South Canterbury figures have increased dramatically (Table 1). Nationally 2,000 (plus) operators farm 200-250 thousand deer. Does that have 38,000 farmers still not involved?

To those early into the business have come the financial rewards they deserve. For them, there was little information from research, less from advisory services and much sceptiscim from financiers and fellow farmers. Fortunately this has changed. Many MAF personnel, veterinarians, researchers and stock and station people are well qualified to assist the potential deer farmer.

Table 1: TRENDS IN DEER FARMING IN MID AND SOUTH CANTERBURY.

\begin{tabular}{lrc}
\hline & 1980 & 1984 \\
\hline Deer Farms & 71 & 113 \\
Deer Numbers & 9040 & 15901 \\
\hline
\end{tabular}

\section{THE FARM OPERATION}

Stock

My farm, of 243 hectares on rolling clay downs, in a 24 inch rainfall area is not ideal deer farming country. The farm has been, and still is, a mixed cropping and sheep unit, pretty typical of coastal South Canterbury/North Otago. I run 1400 Coopworth ewes, 600 ewe hoggets and fatten non replacement lambs, often on a rape or lucerne crop. I will crop this year 26 hectares of wheat, 24 of barley and 16 of peas (which in some years have been for processing). If the season is favourable 6 hectares of Manawa ryegrass will be harvested and some of the 22 hectares of lucerne made into hay.

In the middle of the farm in 1976 I deer fenced, rather timidly, a 2 hectare area, which was out of the public view. I bought 12 mixed sex farm bred, red deer and so started. At the time I did not wish to spend more than I could afford to lose - in hindsight a very conservative approach. The $\$ 100$ a pound for very ordinary velvet in the early years was a great encouragement to expand.

Following a brief and successful joint venture with T.J. Edmonds Ltd, of Baking Powder fame, I now own 190 deer which have 31 hectares available to them. Each year sees us expanding the high fences. My breeding ewe numbers are declining accordingly. I am sure we are in the business to stay.

\section{Fencing}

We are now extending to roadlines for all to observe. Again in hindsight, how much cheaper to have had one high perimeter fence with existing sheep fences deer proofed, by the addition of a couple of hot wires. Adapting sheep fences in this way is $75 \%$ cheaper than traditional post and netting perimeter fences which cost $\$ 6$ per 
metre, including gates. Within paddock electric subdivision can be done for $15 \%$ of this cost $(90 \mathrm{c} / \mathrm{m})$ using $1.4 \mathrm{~m}$ fibreglass standards, with 2 tapes and 2 live strand wires. Most farm bred deer respect electric subdivision with the exception of mature males, which from March through to late winter can get quite aggressive.

\section{Feed requirements}

My deer are grazed on traditional ryegrass/white clover pasture, some with cocksfoot and some with red clover. It seems that if deer only are grazed on a set area, then periods of surplus and shortage are inevitable (Fig. 1). The experts tell us of the necessity of keeping pastures vigorous and well controlled, practically this means conserving hay, silage and/or introducing other livestock. A warning here to those mowing with high speed cutters. Young fawns can lie very low and still in a hay crop, not always in the field where their mothers are grazing. Silage is popular and deer are known to do well on it. Any crops traditionally grown for sheep and cattle can be used either as a break, or on-off system.

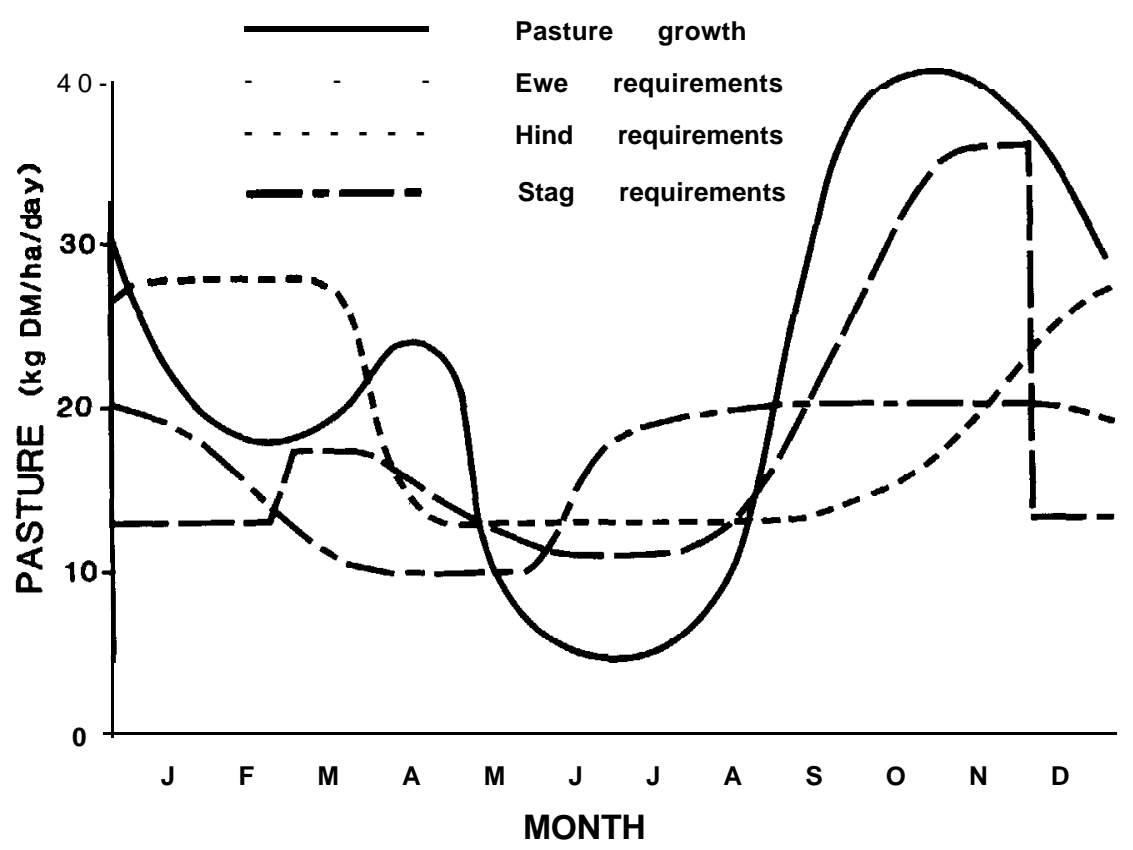

Figure 7: Feed requirements of the breeding ewe, hind and stag (12 su/ha) compared to the South Canterbury downlands pasture growth curve.

For my set-up, winter supplementary feeding for 4 months has been with barley grain and pea vine hay, the residue of the processed peas. A maximum Of $1 \mathrm{~kg}$ barley per adult stag and a bale of hay per 10 plus grass picking would be a daily ration.

\section{Stock health}

Stock health surveys conducted by Noel Beatson from the Timaru MAF, Animal Health Division, show that malignant catarrhal fever (MCF) is still the major killer in this area and probably nationally. I have a strong suspicion that this condition, which causes rapid death, may well be predisposed by insufficient high energy food. There is no known treatment for this virus condition, though research by $\mathrm{Dr}$ Rod Oliver of Wallaceville indicates that a vaccine may be available soon. Death by accident features in the surveys. 
Tuberculosis has caused losses, though fortunately 1 have had no reactors to either whole herd, or individual tests. A word of caution to those buying deer; beware from where you buy, as it can be expensive and a risk to humans, if the incoming animals bring TB with them.

With attention to good feeding, culling for temperament, minimising stressful situations and common sense stockmanship losses should not be excessive certainly lower than with sheep and cattle. I have had to assist hinds with fawning. With the use of the Wapiti type sires and maybe over feeding and under exercise, fawning difficulties must be expected.

Income

My main revenue from the deer in recent times has been velvet sales from the 68 all age males grossing last year $\$ 239$ per animal and $\$ 1600$ per hectare.

There was a hiccup in the market outside New Zealand late last year, due to alleged addition of animal blood into the velvet. The ensuing scandal generated consumer resistance, which will probably see the new season's price considerably less than the $\$ 130$ a $\mathrm{kg}$ paid for top grade product last year.

Sales of sire stags has been worthwhile. With production records and culling I am able to offer superior producing animals. Some cast for age hinds have found a ready market. Most females are retained. In common with other deer farmers, I have the problem of wanting to build breeding numbers versus the desire to cash in on the very lucrative live sale of breeding hinds. Poorer quality and bad mannered stags get a one way ticket to the Deer Slaughter Premises at Ashburton. $\$ 6.70$ per $\mathrm{kg}$ from a $15-17$ month stag dressing out at $58 \mathrm{~kg}$ gives a gross return of $\$ 388$ and a net of $\$ 362$.

Returns from deer are far superior to those from sheep as illustrated by the gross margin of my sheep breeding ewe enterprise compared with that of a red deer breeding hind enterprise selling 15 month stags for venison, and surplus female stock as live sales (Table 2).

Table 2: COMPARISON OF BREEDING EWE AND RED DEER PROFITABILITY.

\begin{tabular}{lc}
\hline Gross Margins & \$/Stock Unit \\
\hline Sheep - J.A. Steven -1983184 & $\$ 28.60$ \\
Deer - Venison -1983184 & $\$ 97.00$ \\
Deer - Venison - at September 1984 & $\$ 117.00$ \\
\hline
\end{tabular}

\section{THEFUTURE?}

Much has been written by an assortment of writers in most magazines and journals. The deer industry has attracted a fair share of media attention. A recent newsletter from the national body of deer farmers (which has a financial membership of 2,000 ) listed some of the recent overseas correspondence. Deer farming New Zealand style has captured world wide interest.

Recent and planned imports of Canadian Elk, European and U.K. Reds are numerous, the imports have generated much interest but whether they will enhance our velvet or venison trade is a matter of conjecture. For my own part I am sticking with the New Zealand Red. They produce the most sought after velvet and the vension readily falls into the premium grades. A national deer recording scheme is being established and is likely to commence with 2,000 hinds under initial recording. A well established and supported national organisation with strong local branches, good liaison, with Veterinarian Association and like institutions, and a game industry board, all operate for the benefit and growth of the industry. 
Game packing houses (feral animals) and deer slaughter premises numbering seven, and situated strategically throughout New Zealand, have a potential killing capacity much in excess of present demand. Our venison markets are mainly in West Germany and Australia, but I understand one of our problems is too little product. Dr Drew of Invermay said at a recent conference, that by 1990 we could have 7,000 tonnes of venison worth $\$ 35$ million. Queen Street investors money, and I expect foreign capital, is invested in the industry not to mention the Stock and Station Companies contribution. Wire netting manufacturers have big back logs of orders and there are understocked deer farms.

These factors, and the recognised ability of deer to convert grass to red meat with a very low fat content gives me considerable confidence for the future of deer farming.

\section{ACKNOWLEDGEMENT}

S.M. Cumberworth, Advisory Services Division, MAF, Timaru. 